\title{
Kinetic ESI-MS studies of potent anti-HIV aptamers based on the G-quadruplex forming sequence d(TGGGAG)
}

\author{
Valeria Romanucci, ${ }^{\dagger}$ Adrien Marchand, ${ }^{\ddagger \S}$ Oscar Mendoza, ${ }^{\ddagger \S}$ Daniele D’Alonzo, ${ }^{\dagger}$ Armando Zarrelli, ${ }^{\dagger}$ \\ Valérie Gabelica, ${ }^{\ddagger \S^{*}}$ and Giovanni Di Fabio ${ }^{{ }^{*}}$
}

\footnotetext{
${ }^{\dagger}$ Department of Chemical Sciences, University of Napoli Federico II, Via Cintia, I-80126 Napoli, Italy; ${ }^{\ddagger}$ IECB, ARNA Laboratory, University of Bordeaux, 33600 Pessac, France; ${ }^{\S}$ Inserm, U869, ARNA Laboratory, Institut National de la Santé et de la Recherche Médicale, 33000 Bordeaux, France.

\section{ELECTRONIC SUPPLEMENTARY INFORMATION: Experimental details}

\section{Table of contents}

$\begin{array}{lr}\text { Synthesis of ODNs }(\mathbf{I}-\mathbf{V I}) & \text { S2 }\end{array}$

$\begin{array}{ll}\text { Sample preparation } & \text { S2 }\end{array}$

$\begin{array}{ll}\text { Electrospray Mass Spectrometry experiments } & \text { S2 }\end{array}$

Spectra of $\mathbf{I}(600 \mu \mathrm{M})$ at different times after addition of $150 \mathrm{mM} \mathrm{NH}_{4} \mathrm{OAc}$ buffer $\quad \mathrm{S} 3$

Zoom spectrum of $\mathbf{I}(600 \mu \mathrm{M})$ after 10 days by the addition of $150 \mathrm{mM} \mathrm{NH}_{4} \mathrm{OAc}$ buffer $\quad \mathrm{S} 3$

Spectra of II $(600 \mu \mathrm{M})$ at different times after addition of $150 \mathrm{mM} \mathrm{NH}_{4} \mathrm{OAc}$ buffer $\quad$ S4

Zoom spectrum of II $(600 \mu \mathrm{M})$ after 10 days by the addition of $150 \mathrm{mM} \mathrm{NH}_{4} \mathrm{OAc}$ buffer $\quad$ S4

Spectra of III $(600 \mu \mathrm{M})$ at different times after addition of $150 \mathrm{mM} \mathrm{NH}_{4} \mathrm{OAc}$ buffer $\quad$ S5

Zoom spectrum of III $(600 \mu \mathrm{M})$ after 10 days by the addition of $150 \mathrm{mM} \mathrm{NH}_{4} \mathrm{OAc}$ buffer

Spectra of IV $(600 \mu \mathrm{M})$ at different times after addition of $150 \mathrm{mM} \mathrm{NH}_{4} \mathrm{OAc}$ buffer $\quad$ S6

Zoom spectrum of IV $(600 \mu \mathrm{M})$ after 10 days by the addition of $150 \mathrm{mM} \mathrm{NH}_{4} \mathrm{OAc}$ buffer $\quad$ S6

Spectra of $\mathbf{V}(600 \mu \mathrm{M})$ at different times after addition of $150 \mathrm{mM} \mathrm{NH}_{4} \mathrm{OAc}$ buffer $\quad$ S7

Spectra of VI $(600 \mu \mathrm{M})$ at different times after addition of $150 \mathrm{mM} \mathrm{NH}_{4} \mathrm{OAc}$ buffer $\quad$ S7

Native Polyacrylamide Gel Electrophoresis (PAGE) $\quad$ S8

$\begin{array}{ll}\text { Quadruplex preparation and CD experiments } & \text { S9 }\end{array}$ 


\section{Synthesis of ODNs (I-VI).}

The oligomers I-VI were synthesized, starting from functionalized CPG support with $0.07-0.08 \mathrm{meq} / \mathrm{g}$ initial loading, on which the sequence d(TGGGAG) was assembled in a standard manner. Starting with $100 \mathrm{mg}$ of commercially available CPG-dG support with $0.10 \mathrm{meq} / \mathrm{g}$ initial loading, and after the assembly of the sequence d(TGGGA), an additional coupling with alcohol phosphoramidite building blocks was then performed. Target oligomers I-VI were detached from the solid support and deprotected by treatment with $\mathrm{Et}_{3} \mathrm{~N} /$ pyridine $(1: 1, \mathrm{v} / \mathrm{v})$ at $50{ }^{\circ} \mathrm{C}$ for $1 \mathrm{~h}$, followed by treatment with conc. aq. ammonia at $50{ }^{\circ} \mathrm{C}$ for $5 \mathrm{~h}$. The combined filtrates and washings were concentrated under reduced pressure, re-dissolved in $\mathrm{H}_{2} \mathrm{O}$, and analysed and purified by HPLC. Purification of the crude conjugated oligonucleotides I-VI was carried out on Phenomenex RP18 column $(250 \times 21.20 \mathrm{~mm}, 10 \mathrm{~mm})$ using a linear gradient of $\mathrm{CH}_{3} \mathrm{CN}$ (acetonitrile) in 0.1 M TEAA (triethylammonium acetate) in $\mathrm{H}_{2} \mathrm{O}$, pH 7.0 from $5 \%$ to $100 \%$ over 30 minutes at a flow rate of $1.5 \mathrm{~mL} / \mathrm{min}$ with detection at $260 \mathrm{~nm}$. In all cases 50-80 OD units of pure I-VI could be on average recovered starting from $100 \mathrm{mg}$ of functionalized solid support (average yields 16-25\%). The purity of each ODN (higher than 98\%) was confirmed on analytical RP18 column (LUNA, C18(2), $250 \times 4.6 \mathrm{~mm}, 5 \mu \mathrm{m}$ ). The modified oligonucleotides were characterized by ESI mass spectrometry in the negative mode, in all cases giving masses in accordance with the expected values.

\section{Sample preparation.}

Stock ODNs solutions were prepared at $1 \mathrm{mM}$ in water doubly distilled in house, and stored at $-20{ }^{\circ} \mathrm{C}$. The stock concentrations were determined by UV absorbance at $260 \mathrm{~nm}$ measured on an Agilent Cary $100 \mathrm{UV}$ spectrophotometer. UV measurements at $260 \mathrm{~nm}$ were carried out using the nearest-neighbour calculated molar extinction coefficient of $\mathrm{d}($ TGGGAG) $\varepsilon=62500 \mathrm{~cm}-1 \mathrm{M}-1$, not taking into consideration the contribution of the 5'-aromatic label.

Water was nuclease-free grade from Ambion (Applied Biosystems, Lennik, Belgium). Ammonium acetate $\left(\mathrm{NH}_{4} \mathrm{OAc}\right.$, Ultra for Molecular Biology, Fluka) was purchased from Sigma-Aldrich (Saint-Quentin Fallavier, France). Annealing experiments were performed at $80{ }^{\circ} \mathrm{C}$ heating for 5 minutes and then a fast cooling to $20{ }^{\circ} \mathrm{C}$ were carried out. Stock solutions of $600 \mu \mathrm{M}$ of each ODN were obtained by diluition of the samples in $150 \mathrm{mM} \mathrm{NH}_{4} \mathrm{OAc}$. For all kinetics experiments, $50 \mu \mathrm{M} \mathrm{d}\left(\mathrm{T}_{6}\right)$ (monoisotopic mass $1762.318 \mathrm{Da}$ ) was added to each stock solution in order to follow the intensities of the reactant (single strand, ss), and complexes (dimer, trimer, tetramer and octamer) relative to that of the reference. The solutions were stored at $20{ }^{\circ} \mathrm{C}$ for MS measurements performed in 14 days. The samples are agitated, loaded into the syringe and the spray is initiated in few minutes.

\section{Electrospray Mass Spectrometry experiments.}

Native ESI-MS experiments were performed on LCT Premier mass spectrometer (Waters, Man- chester, U.K.). The electrospray ion source (ESI) was operated in negative ion mode and the voltage is set to $2200 \mathrm{~V}$. The desolvation temperature is $60{ }^{\circ} \mathrm{C}$, and the gas temperature is $40{ }^{\circ} \mathrm{C}$. In all experiments provided in $\mathrm{NH}_{4} \mathrm{OAc}$, three spectra at different source cone voltages $(50 \mathrm{~V}, 100 \mathrm{~V}, 200 \mathrm{~V})$ have been recorded to be sure about the soft conditions of analysis. The source pressure is increased to 45 mbar (measured by a Center Two probe, Oerlikon Leybold Vacuum, Cologne, Germany). The syringe injection rate is $200 \mu \mathrm{L} / \mathrm{h}$. MS spectra shown are the sum of 3 min accumulations ( 1 scan per $1.1 \mathrm{~s}$ ). The spectra were smoothed (mean function, $2 \times 15$ channels), background-subtracted (polynomial order $=99,0.1 \%$ below curve, tolerance 0.010 ), converted to centroid (peak width 15 channels, reconstructed area of the top $80 \%$ of the peak), and 
recalibrated using the reference as a lock mass $\left[\mathrm{d}\left(\mathrm{T}_{6}\right)\right]^{2-}$ monoisotopic peak at $\mathrm{m} / \mathrm{z}=880.153$. The total single strand concentration injected was $20 \mu \mathrm{M}$ with $1,6 \mu \mathrm{M} \mathrm{d}\left(\mathrm{T}_{6}\right)$ as internal reference.

Spectra of $\mathbf{I}(600 \mu \mathrm{M})$ at different times after addition of $150 \mathrm{mM} \mathrm{NH}_{4} \mathrm{OAc}$ buffer
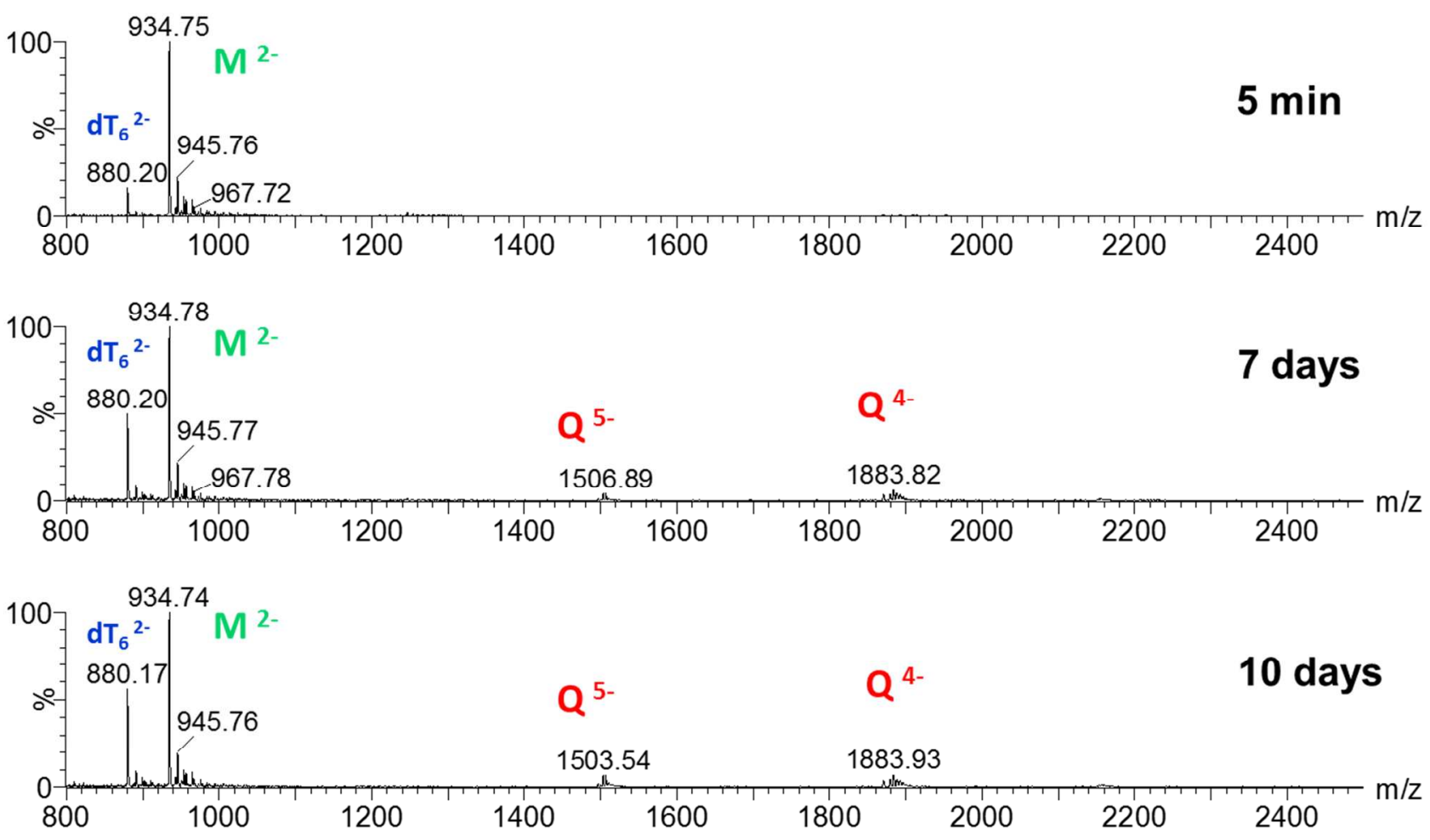

Zoom spectrum of I $(600 \mu \mathrm{M})$ after 10 days by the addition of $150 \mathrm{mM} \mathrm{NH}_{4} \mathrm{OAc}$ buffer

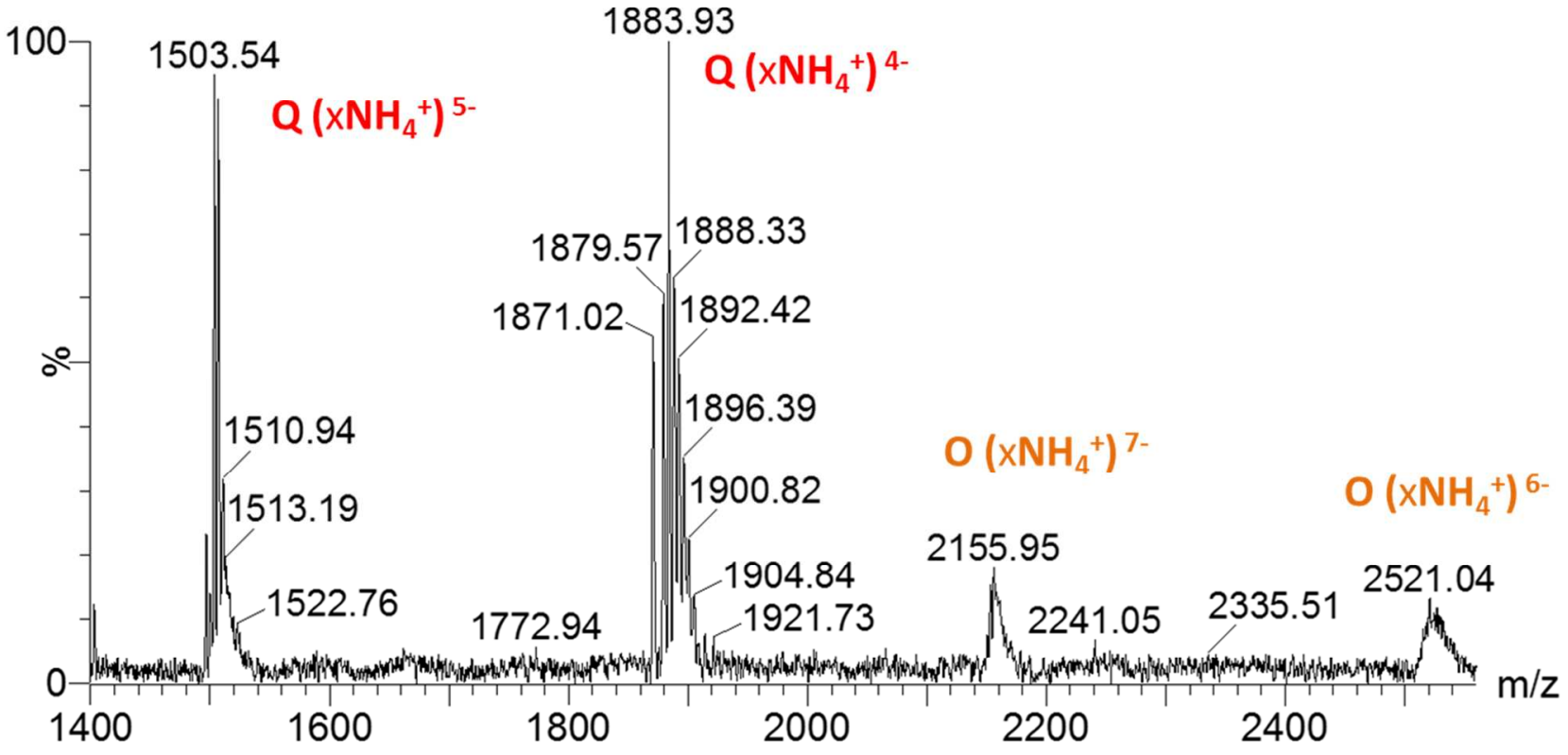


Spectra of II $(600 \mu \mathrm{M})$ at different times after addition of $150 \mathrm{mM} \mathrm{NH}_{4} \mathrm{OAc}$ buffer
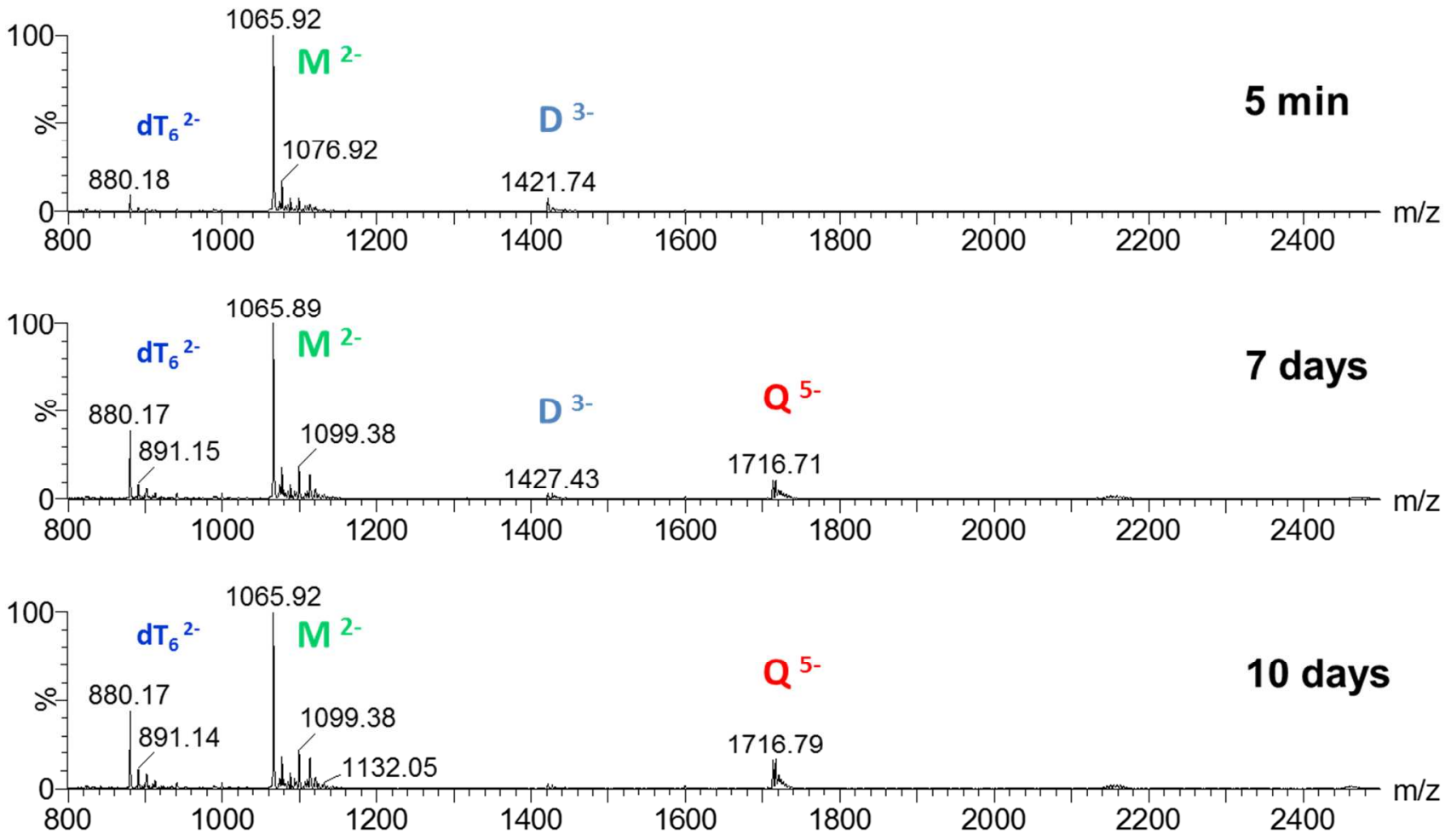

Zoom spectrum of II $(600 \mu \mathrm{M})$ after 10 days by the addition of $150 \mathrm{mM} \mathrm{NH}_{4} \mathrm{OAc}$ buffer

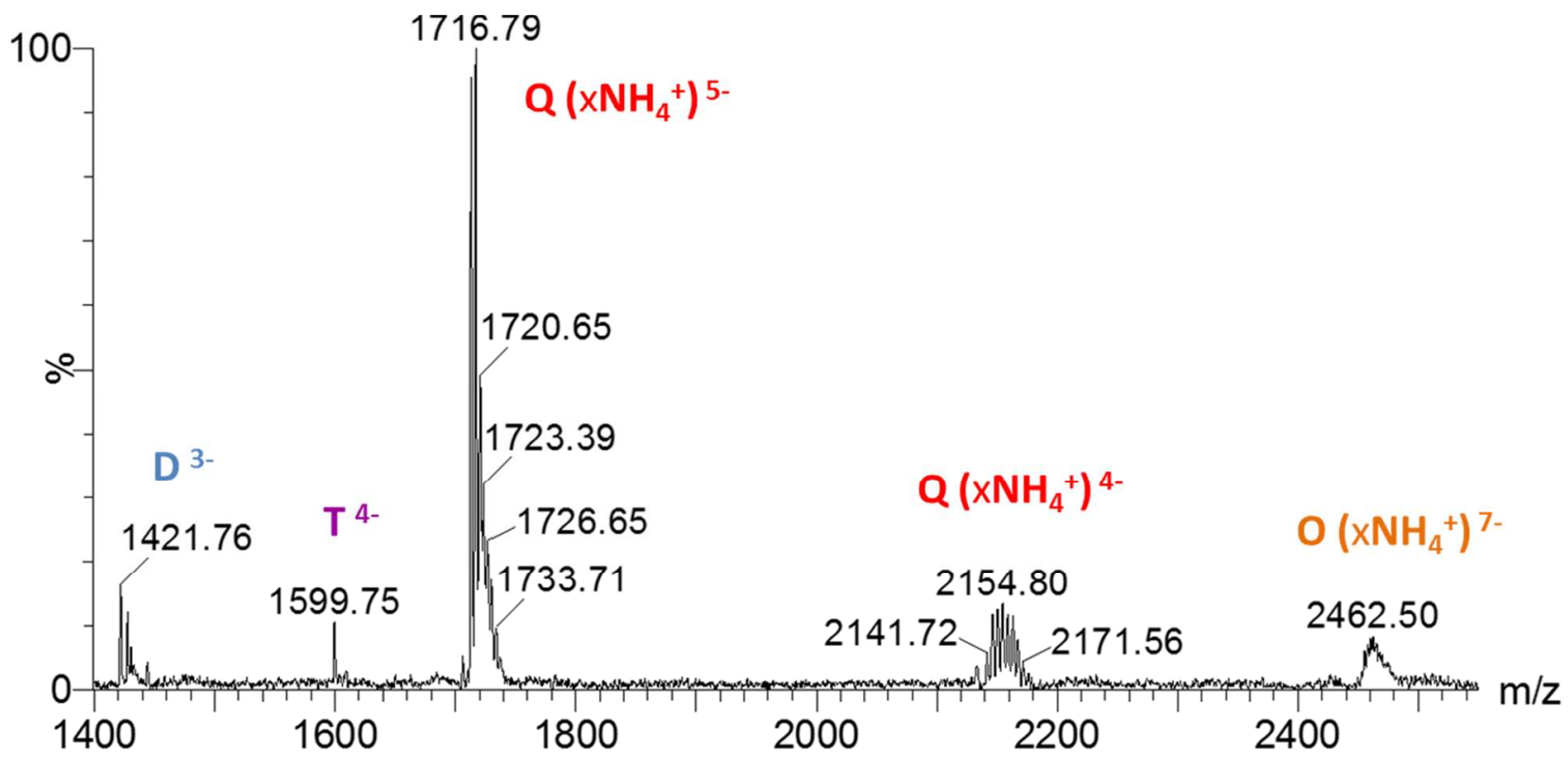


Spectra of III $(600 \mu \mathrm{M})$ at different times after addition of $150 \mathrm{mM} \mathrm{NH}_{4} \mathrm{OAc}$ buffer
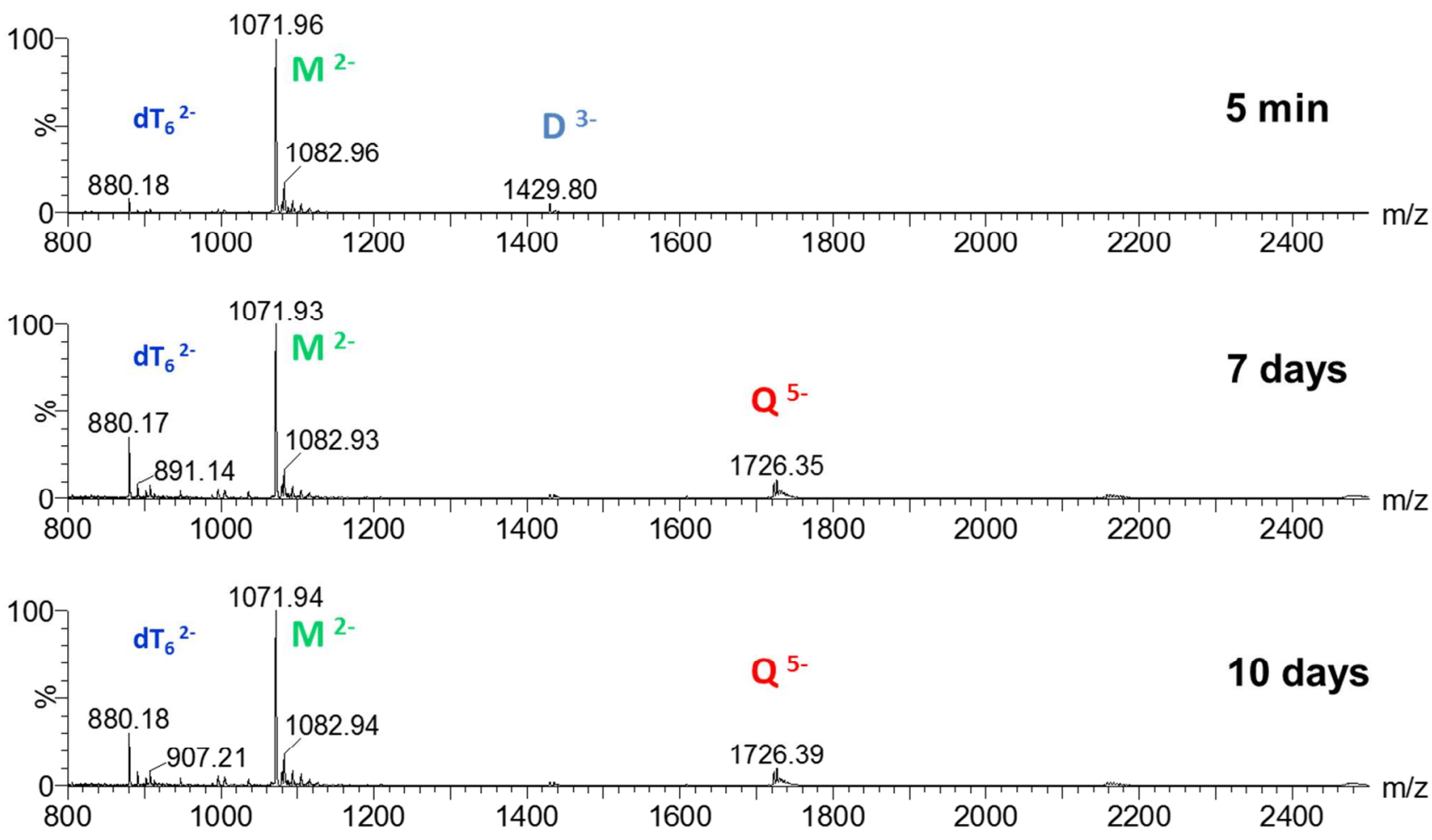

Zoom spectrum of III $(600 \mu \mathrm{M})$ after 10 days by the addition of $150 \mathrm{mM} \mathrm{NH}_{4} \mathrm{OAc}$ buffer

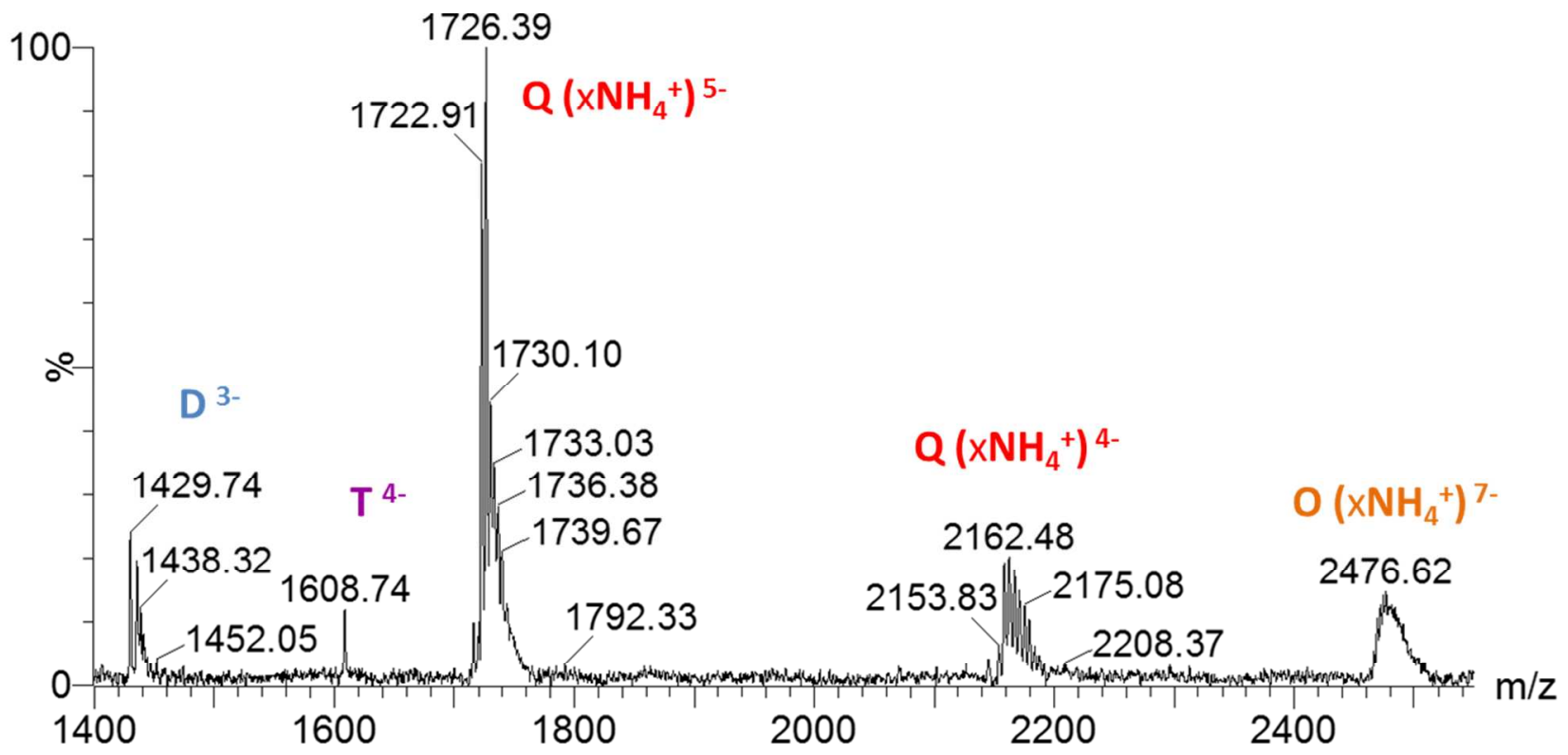


Spectra of IV $(600 \mu \mathrm{M})$ at different times after addition of $150 \mathrm{mM} \mathrm{NH}_{4} \mathrm{OAc}$ buffer
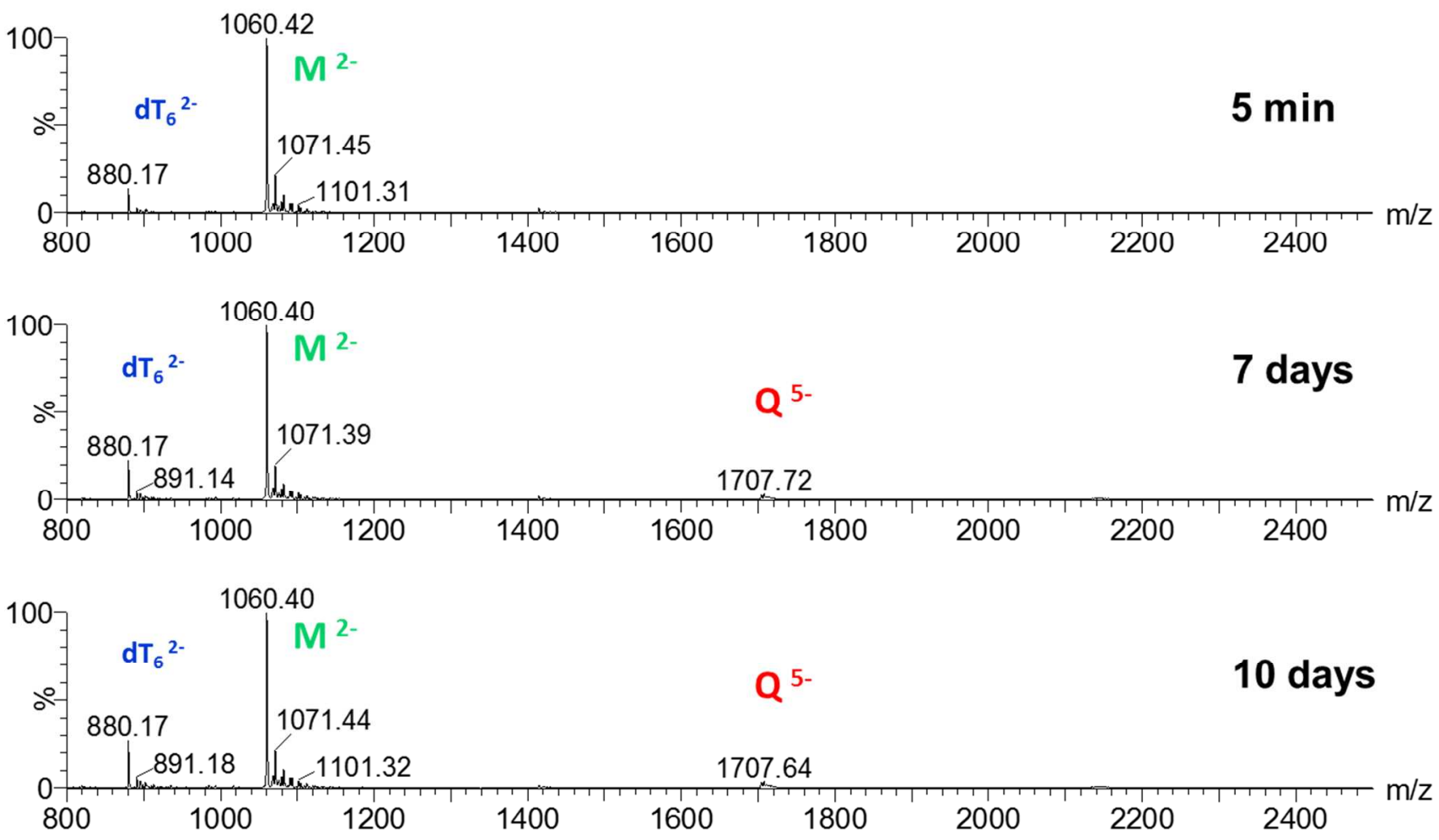

Zoom spectrum of IV $(600 \mu \mathrm{M})$ after 10 days by the addition of $150 \mathrm{mM} \mathrm{NH}_{4} \mathrm{OAc}$ buffer

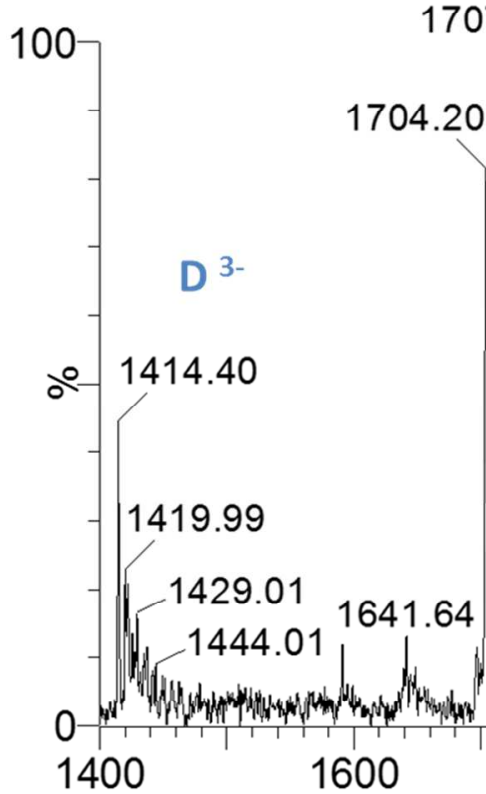

1707.64

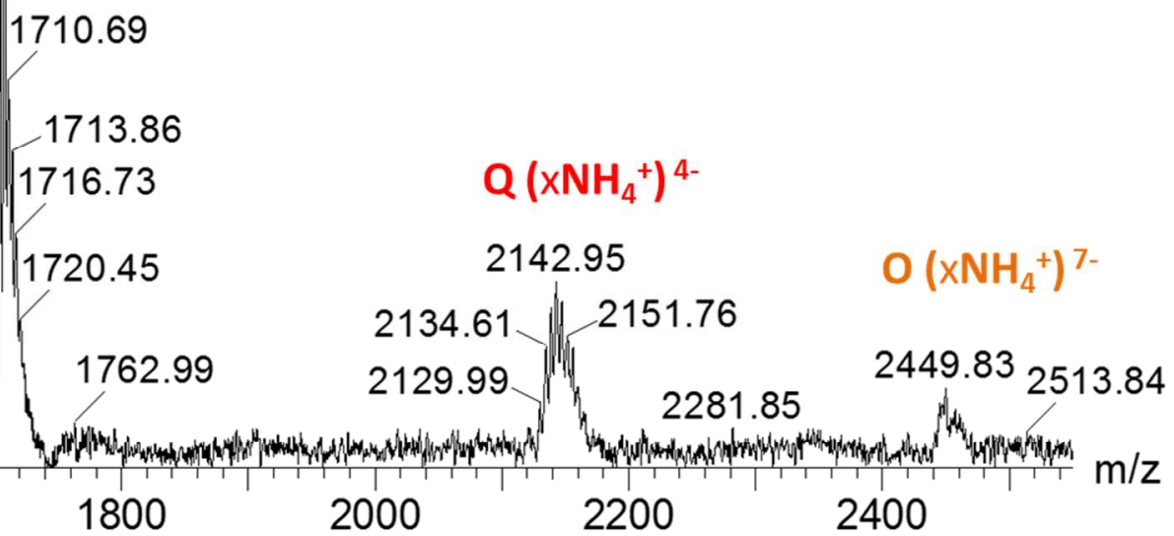


Spectra of $\mathbf{V}(600 \mu \mathrm{M})$ at different times after the addition of $150 \mathrm{mM} \mathrm{NH}_{4} \mathrm{OAc}$ revealed after 7 days the tendency of compound to aggregate.
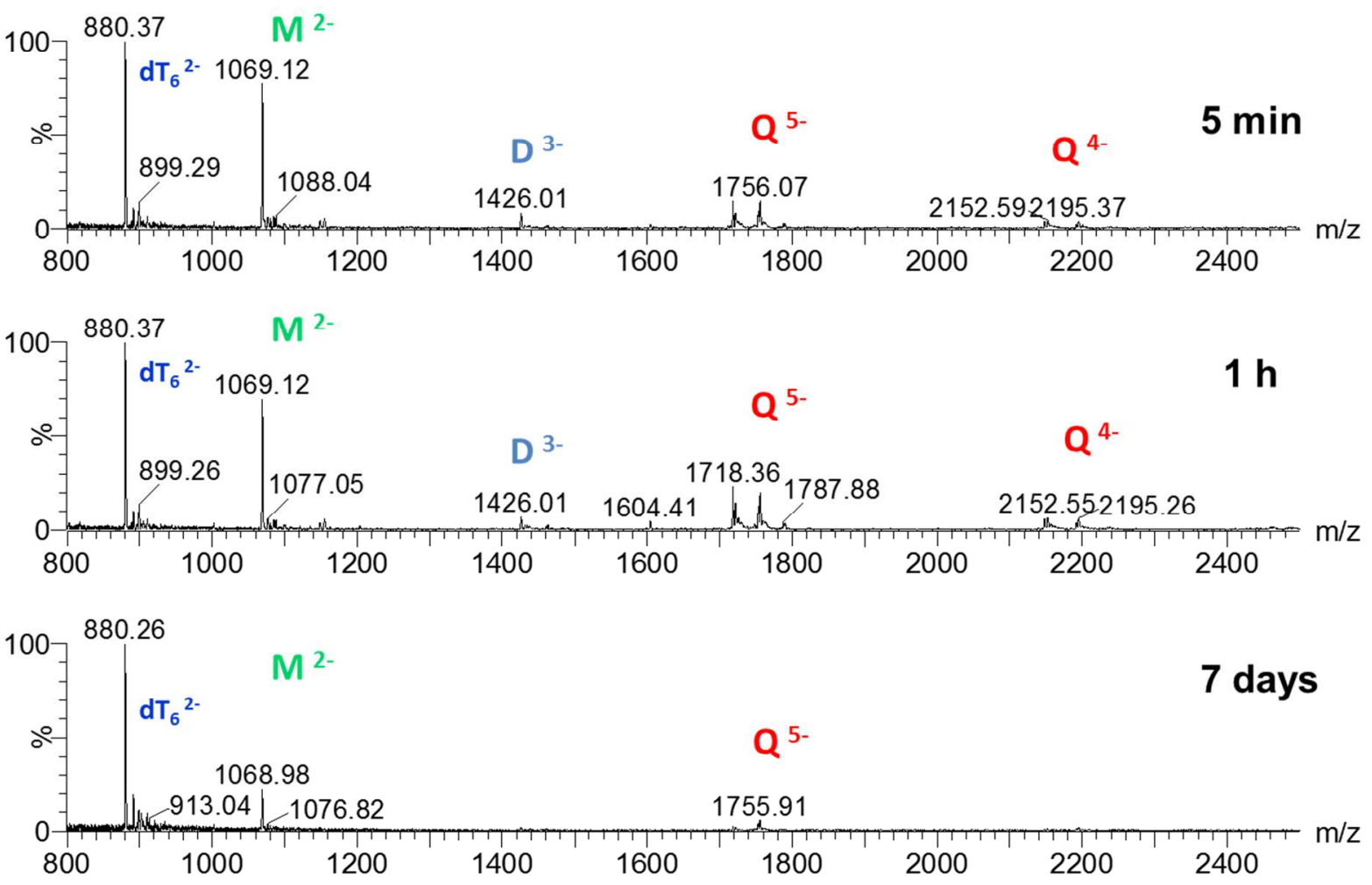

Spectra of VI $(600 \mu \mathrm{M})$ at different times after the addition of $150 \mathrm{mM} \mathrm{NH}_{4} \mathrm{OAc}$ revealed just after 1 hour the tendency of compound to aggregate.
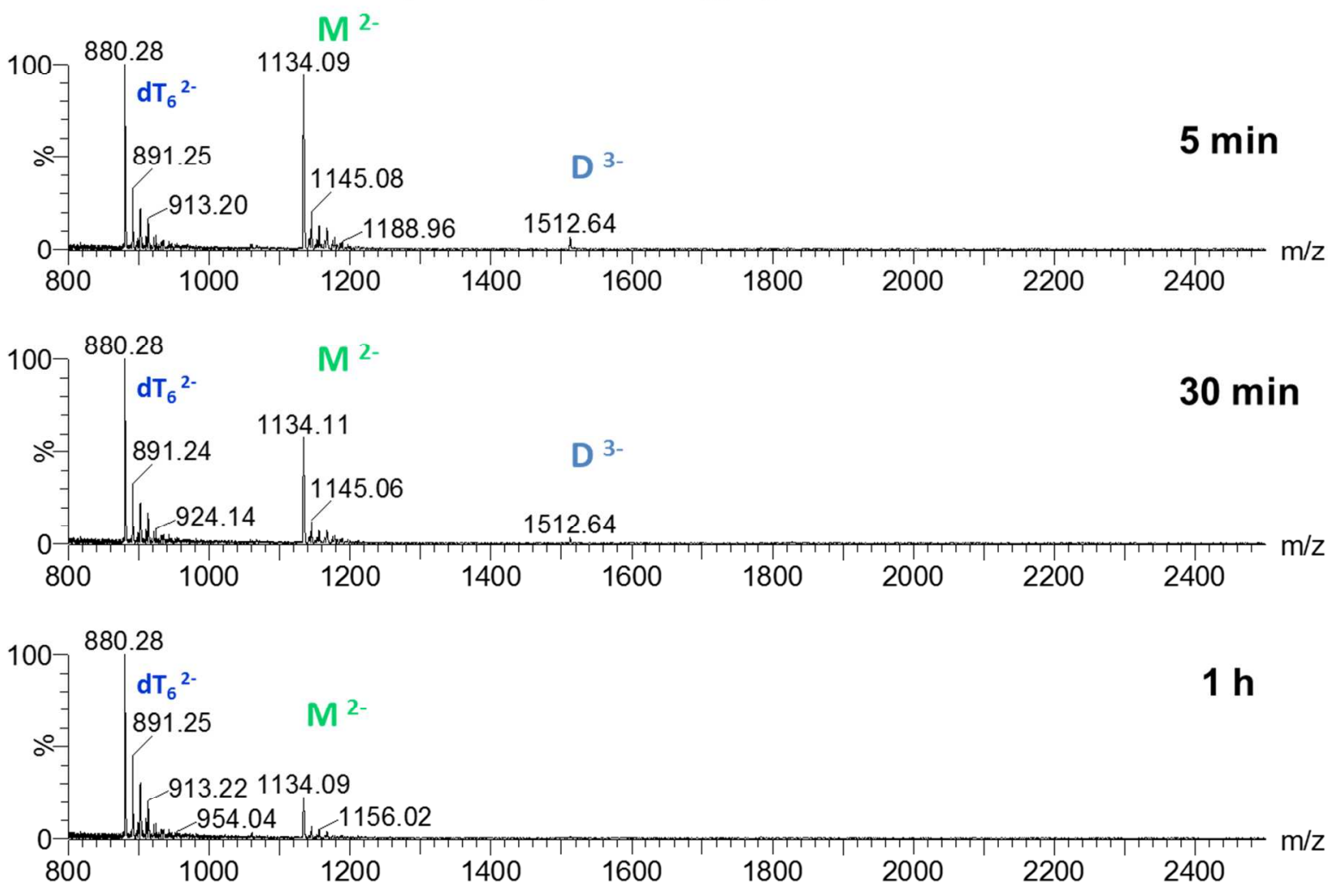
Native Polyacrylamide Gel Electrophoresis (PAGE).

Non-denaturing polyacrylamide gel electrophoresis (PAGE) was carried out on $15 \%$ polyacrylamide gel and running buffer (TBE $5 \mathrm{x}$ ) containing $10 \mathrm{mM} \mathrm{KCl}$. ODN samples of $5 \mathrm{mM}$, obtained by diluting the annealed stock solutions, and glycerol of $10 \%$ were loaded on the gel. Oligothymidylate markers, 9 to 100 nucleotide-long (dT9, dT15, dT22, dT30, dT45, dT57 and dT100) were also loaded on the gel. The gel was run at $26{ }^{\circ} \mathrm{C}$ at constant voltage (110 V) for $2.5 \mathrm{~h}$. After electrophoresis, the gel was visualised by UV shadowing with a DNR bio-imaging, MF-ChemiBIS 3.2 system.

Aiming at observing the mobility of all complexes ( monomer, G4 and octameric complexes), the sequences (I-IV) were loaded on the gel in both conditions: single stranded (ss) conditions (no potassium added, indicated by “_”) and G4 conditions (stock solution at $4.5 \mathrm{mM}$ of oligonucleotides in $100 \mathrm{mM} \mathrm{KCl}$, indicated by "+") $\mathrm{d}\left(\mathrm{T}_{6}\right.$ ) was used as a singlestranded 6-mer marker and $\mathrm{d}\left(\mathrm{TG}_{4} \mathrm{~T}\right)$ annealed in $0.1 \mathrm{M}$ potassium buffer, was used as a tetramolecular G-quadruplex marker $\left[\mathrm{d}\left(\mathrm{TG}_{4} \mathrm{~T}\right)\right]_{4}$.

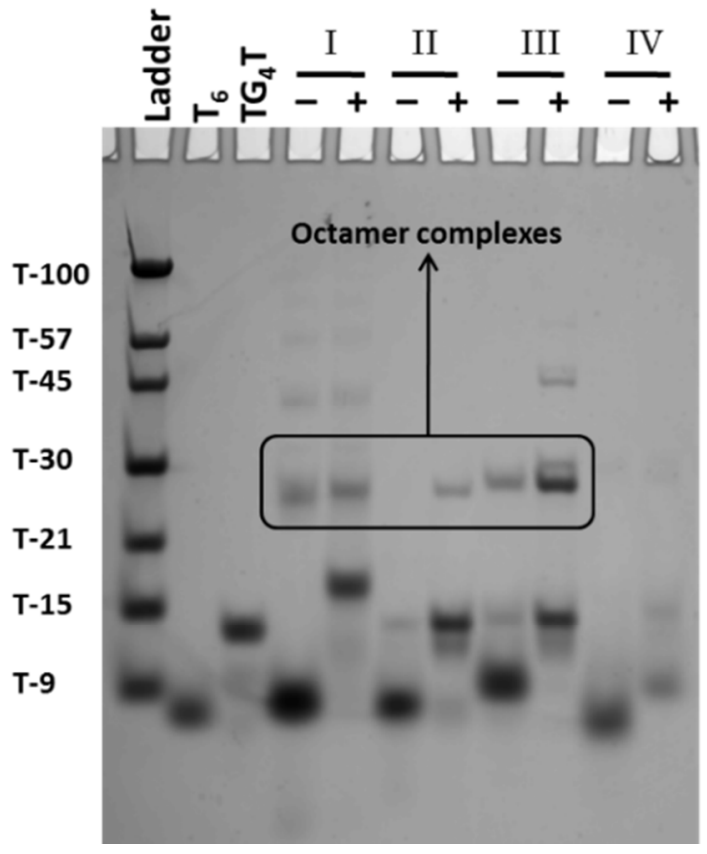




\section{Quadruplex preparation and CD experiments.}

The quadruplex complexes were obtained by dissolving the lyophilized oligonucleotides at $5 \times 10-5 \mathrm{M}$ single strand concentration in $150 \mathrm{mM} \mathrm{NH} \mathrm{H}_{4} \mathrm{OAc}$ buffer. The solution was annealed by heating at $80{ }^{\circ} \mathrm{C}$ for $5 \mathrm{~min}$ and slow cooling to room temperature. CD spectra were collected from 220 to $320 \mathrm{~nm}$, at $20 \mathrm{~nm} / \mathrm{min}$, with a response time of $16 \mathrm{~s}$ and at $2 \mathrm{~nm}$ bandwidth.

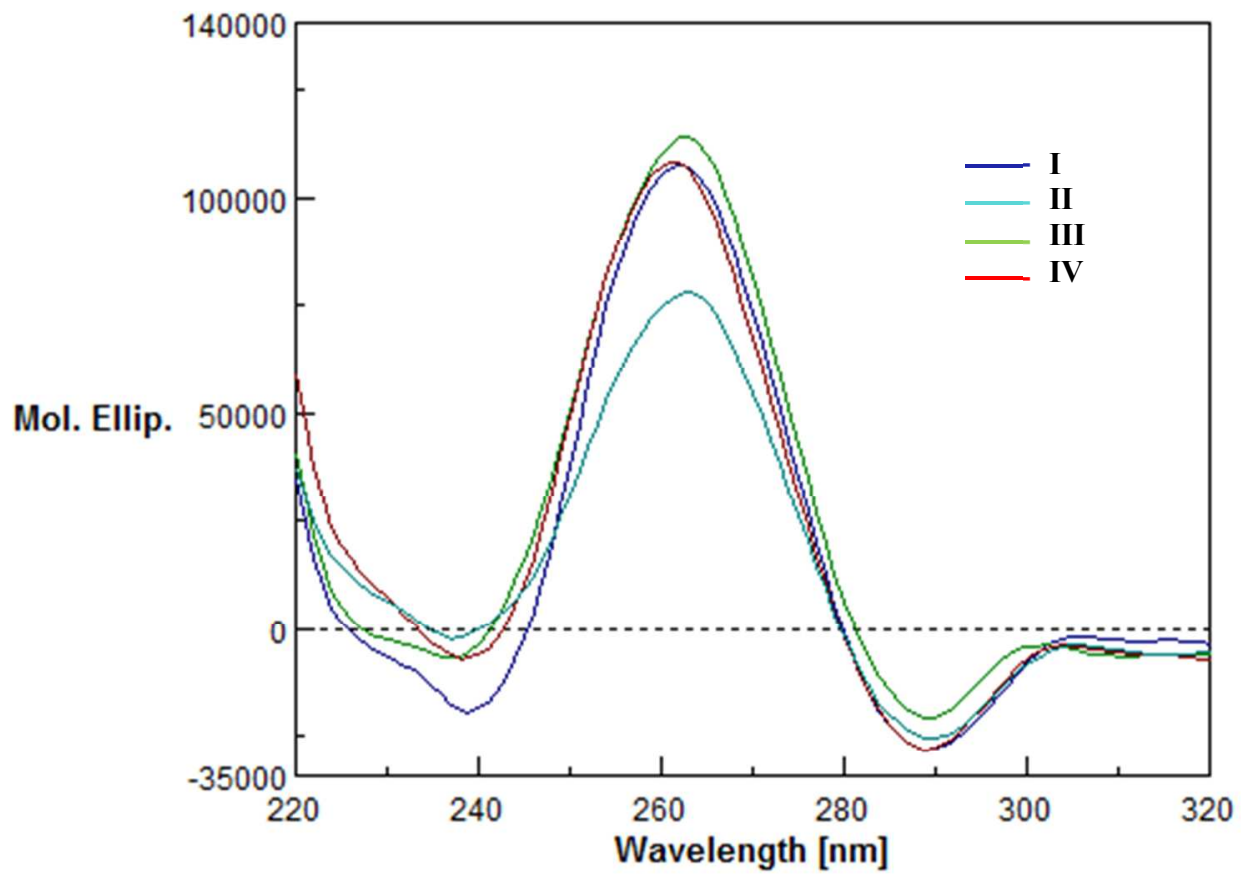

